\title{
腎細胞癌に扔ける胎盤性ロイシンアミノペプチダーゼ (P-LAP)の意義
}

岐阜大学医学部泌尿器科学教室（主任：西浦常雄教授）

$\begin{array}{lrllll}\text { 栗山 } & \text { 学 } & \text { 篠田 } & \text { 育男 } & \text { 山本 } & \text { 直樹 } \\ \text { 竹内 } & \text { 敏視 } & \text { 高橋 } & \text { 義人 } & \text { 西浦 } & \text { 常雄 }\end{array}$

福井医科大学泌尿器科学教室（主任：河田幸道教授）

岡野学河田幸道

\section{CLINICAL EVALUATION OF SERUM PLACENTAL LEUCINE AMINOPEPTIDASE (P-LAP) ACTIVITY IN RENAL CELL CARCINOMA}

\author{
Manabu Kuriyama, Ikuo Shinoda, Naoki Yamamoto, Toshimi Takeuchi, \\ Yoshito Takahashi and Tnuneo Nishiura \\ Department of Urology, Gifu University School of Medicine \\ (Director; Prof. T. Nishiura, M.D.) \\ Manabu Okano and Yukimichi Kawada \\ Department of Urology, Fukui Medical Colleage \\ (Director; Prof. Y. Kawada, M.D.)
}

Serum placental leucine aminopeptidase (P-LAP) activities were measured using leucyl- $p$-nitroanilide as a substrate and coexisting other LAP activities were blocked with $2 \mathrm{mM}$ of L-methionine and evaluated clinically as a tumor marker of renal cell carcinoma. From the mean \pm 2 S.D. in normal male subjects, 22 $\sim 67 \mathrm{G}-\mathrm{R}$ unit was decided as normal range in male cases. Based upon Mizutani's report, 20 49G-R unit was similarly regarded to be normal range of females. A total of 243 sera from various urological diseases including 47 of renal cell carcinoma were examined for serum P-LAP values. Positive rates in major diseases were as follows; $3 \%(4 / 135)$ of normal males, $50 \%(15 / 30)$ of male and $18 \%(3 / 17)$ of female renal cell carcinoma, $14 \%(6 / 44)$ of male and $11 \%(1 / 9)$ of female uroepithelial tumor, and $5 \%(1 / 20)$ of male and $38 \%(3 / 8)$ of female chronic renal failure. By students' t test, a group of renal cell carcinoma showed statistical high serum P-LAP values in male cases $(\mathrm{p}<0.05)$. Serum P-LAP values in 14 patients with renal cell carcinoma changed in parallel to clinical courses. However, serum P-LAP and LAP activities showed a strong correlation $(r=0.799)$. These results suggest that determination of serum P-LAP activities may be useful for detection and follow-up of renal cell carcinoma, especially in male cases. Moreover, development of an immunological assay for specific determination of P-LAP must be necessary for avoiding cross reaction with other aminopeptidases and this assay system will clarify the significance of P-LAP as a tumor marker of renal cell carcinoma (Supported in part by Grant-in-aid from Ministry of Education, Japan).

要旨：腎細胞癌における胎盤性ロイシンアミノペプチダーゼ (placental leucine aminopeptidase, P. LAP)の腫瘍マーカーとしての意義を臨床的に検討した. 血清 P-LAP 值の測定は, leucyl-p-nitroanilide を基質とする酵素法で行ない，共存する他の LAP 活性を，L-methionine で阻害した。 135例の健常男性 例の血清 P-LAP 值は, 24.6 74.7G-R unit に分布し, この群の平均 $\pm 2 S . D$. 值から, 22 67G-R unit を男性例の正常值とみなした。一方, 非妊娠女性例の正常值は, 水谷らの報告に基づいて, 20〜 49G-R unit とした。各種尿路疾患243例の陽性率は腎細胞癌；男性50\%(15/30)，女性18\%(3/17)，尿路上皮腫瘍； 男性 $14 \%$ (6/53), 女性 $11 \%(1 / 9)$, 前立腺癌；18\%（6/33），良性腎疾患；男性 $5 \%(1 / 20)$ ，女性 $0 \%$ (0/1), 慢性腎不全 ; 男性 $5 \%$ （1/20), 女性 $38 \%$ （3/8）が主なものであった。血清 P-LAP 值の推移は, 
14例の腎細胞癌患者の臨床経過と，よく一致していた．以上のように，血清 P-LAP 值の測定は，特に男 性症例に扣いて, 腎細胞癌の診断と経過観察に有力な生化学マーカーとなりらる可能性を示唆していた が，酵素法による測定では，血清 LAP 值との相関も高く（ $\mathrm{r}=0.799 ，$ 腎細胞癌群), 交叉反応は避けら れなかった。より感度上昇を得るためにも，免疫学的測定手技の開発が望まれた。

\section{はじめに}

腎細胞癌の診断，再発の発見は，現在のところ，腎 孟造影，超音波検查， CT，血管造影などの画像診断技 術に負うところが多く, 生化学的マーカーに乏しいの が現状である ${ }^{122}$ ．以前から用いられてきた，血沈， $\alpha_{2}$ グロブリン分画, CRP などは, いずれも nonspecific で あり，炎症の併存によって修飾されやすいものでも あった。適切な化学療法, 放射線療法について一定の 見解の得られていない本疾患では，早期診断と適切な フォローアップのみが, 治癒切除の施行と生存率向上 の唯一の方法であり, この意味でも, 高い感度と特異 性を有する「腫瘍マーカー」の確立が望をれるところ である。

本論文では，胎盤組織だけでなく腎腫瘍組織にも見 出されている3 ${ }^{3}$ 胎盤性ロイシンアミノペプチダーゼ (placental leucine aminopeptidase, P-LAP) の，腎 細胞癌における意義を臨床的に検討した。

\section{方法および対象}

血清 P-LAP 值の測定は, 酵素法で行なった。即ち, L-leucyl-p-diethylanilide を合成基質とし，生成され た $p$-diethylaminoanilide に, 1-nephtol-2-sulfonic acidにて酸化縮合させ,生じた青色色素を650nm の吸 光度で測定した（図 1)，この基質では，共存する他の LAP 活性も測定しているため, $2 \mathrm{mM}$ の L-methionine を共存させてブロックした，測定単位は，GoldbargRutenburg unit（G-R unit）と表示し, G-R unit $\times$ $0.2425=\mathrm{IU} / l$ の関係が成立する.

P-LAP 值を測定した検体は，378血清(男性343，女
性35）であった，疾患別内訳は，健常成人男性135例， 腎細胞癌47例(男性 30 , 女性 17), 尿路上皮腫瘍53例(男 性 44 , 女性 9), 前立腺癌 33 例, 他の男性泌尿器癌 25 例, 前立腺肥大症25例，良性腎疾患21例（男性 20 , 女性 1), 血液透析療法施行中の慢性腎不全28例（男性20, 女性 8 ), 前立腺炎玉たは副鼻丸炎 9 例, 男性例の転移性腎 腫瘍 2 例であった。血清は，当科および関連病院から 得られ，使用までー $70^{\circ} \mathrm{C}$ に保存された。また，採血 時，全ての患者は治療前の状態であった.

血清 P-LAP 值の正常値については，男性例は今回 の検討で決定し，女性例では水谷らの報告4)に基づい て, 平均 \pm 2 S.D. 值から, 20 49G-R unit とした.

\section{結果}

まず，135例の健常成人男性の血清 P-LAP 值を測定 し，年齢別分布掞よび正常值の決定を行なった。各 10 歳毎の血清 P-LAP 值の分布は, 表 1 のようになり, 24.6から74.7G-R unit に分布していたが，年齢群間に

表 1 Serum P-LAP values in normal male subjects by Age

\begin{tabular}{rccccc}
\hline \multirow{2}{*}{ Age } & \multirow{2}{*}{$\begin{array}{l}\text { \# of } \\
\text { examined }\end{array}$} & \multicolumn{5}{c}{ Serum P-LAP (G-R unit) } \\
\cline { 3 - 6 } & & Range & mean \pm S.D. & $\geqq 67^{\text {a) }}(\%)$ & $\geqq 77^{\text {b) }}(\%)$ \\
\hline 19 & 3 & $52.4-67.7$ & $54.13 \pm 12.79$ & $1(33)$ & 0 \\
$20-29$ & 52 & $24.6-68.0$ & $42.75 \pm 9.87$ & $1(2)$ & 0 \\
$30-39$ & 44 & $29.1-74.7$ & $45.46 \pm 11.57$ & $2(5)$ & 0 \\
$40-49$ & 11 & $33.0-65.6$ & $46.53 \pm 11.96$ & 0 & 0 \\
$\geqq 50$ & 25 & $27.6-66.0$ & $42.54 \pm 11.05$ & 0 & 0 \\
\hline Total & 135 & $24.6-74.7$ & $44.16 \pm 10.93$ & $4(3.0)$ & 0 \\
\hline
\end{tabular}

a) 67 G-R unit : mean +2S.D. of normal male subject.

b) 77 G-R unit : mean+3S.D. of normal male subject.

図 1 測定原理
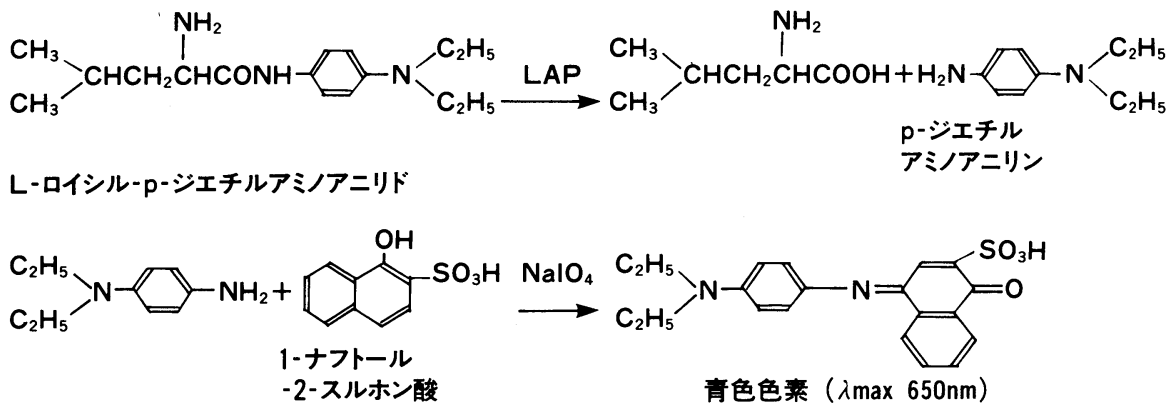
図 2 Distribution of serum P-LAP values in normal males

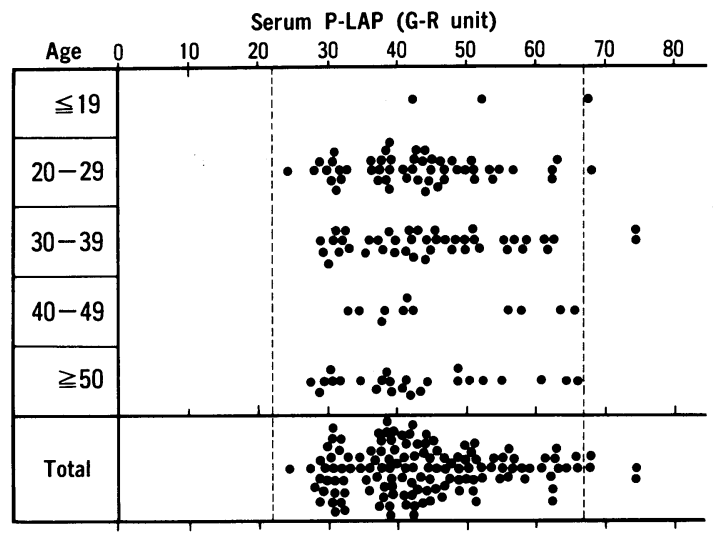

Both broken lines indicate normal range in male cases (22-67 G-R unit).

差は認めなかった(図 2 ). この群の平均土標準偏差(S. D.)值は, $44.16 \pm 10.93 \mathrm{G}-\mathrm{R}$ unit となり, 平均士2S.D. 值が66.12, +3S.D. 值が76.95G-R unit となった. 67 G-R unit 以上を示した例は，10歳代，20歳代の各 1 例 および30歳代の 2 例であり，全体の $3.0 \%$ あったた。 た，77G-R unit 以上の例は認めなかった。

次いで, 378例の各種疾患の血清 P-LAP 值の一覧を 表 2 に示した，男性例の正常上限値を，前述のように 67G-R unit とすると, 健常群の $3 \%$, 腎細胞癌群の $50 \%(15 / 30)$ ，尿路上皮腫瘍の $14 \%(6 / 44)$ ，前立腺癌 の $18 \%$ (6/33), 睪丸腫瘍をはじめとする他の泌尿器癌
の $4 \%(1 / 25)$ が，陽性となった。 また，良性疾患で は，良性腎疾患，慢性腎不全の招の扮のの $5 \%$ （とも に $1 / 20)$ ，前立腺炎/副粹丸炎の $11 \%(1 / 9)$ が陽性を示 したが，25例の前立腺肥大症， 2 例の転移性腎腫瘍で は陽性例は認めなかった。一方，女性例では，腎細胞 癌17例中 3 例 (18\%)，尿路上皮腫瘍の 9 例中 1 例 （11\%)，慢性腎不全患者 8 例中 3 例（38\%）が，陽性 の49G-R unit を越し，水腎症の 1 例では, 31.8G-R unit と正常であった。極端な高值例は，慢性腎不全群の 2 例に観察された. Students' $t$ test による有意差検定で は，男性例に打いて，腎細胞癌群は，尿路上皮腫場， 前立腺癌群に対して $5 \%$ ，その他のグループに対して は $1 \%$ 末満の危険率で，有意に高値の P-LAP レベル を示した(図 3 )。しかし，女性例では，腎細胞癌群は， 尿路上皮腫腸群に対して有意差なく，逆に慢性腎不全 群が，この 2 群に対して $5 \%$ 未満の危険率で有意に高 值であった（図 4).

一方，P-LAP 值と，日常検査で LAP 值として測定 されている arylamidase (AA) 值との相関を検討した (図 5 )。同時測定の行なわれていた腎細胞癌群16例の 相関係数 $(\mathrm{r})$ は，0.799，その他の疾患を含む 22 例でも $\mathrm{r}=0.669$ と高い相関性を示していた。

最後に, 14例の腎細胞癌患者の臨床経過と血清 P. LAP 值の変動を検討した。血清 P-LAP 值は, 根治手 術後，時期的なズレは認められるものの，正常值内へ 収束する傾向を示し，腫瘍の残存する症例では，異常

表 2 Serum P-LAP values in various diseases

\begin{tabular}{|c|c|c|c|c|c|c|c|c|c|}
\hline \multirow{3}{*}{ Group } & \multirow{3}{*}{$\begin{array}{l}\# \text { of } \\
\text { examined }\end{array}$} & \multicolumn{7}{|c|}{ Serum P-LAP (G-R unit) } & \\
\hline & & \multicolumn{4}{|c|}{ Male } & \multicolumn{4}{|c|}{ Female } \\
\hline & & $\begin{array}{l}\text { \# of } \\
\text { cases }\end{array}$ & Range & mean \pm S.D. & $\geqq 67(\%)$ & $\begin{array}{l}\# \text { of } \\
\text { cases }\end{array}$ & Range & mean \pm S.D. & $\geqq 49^{b}(\%)$ \\
\hline Normal controls & 135 & 135 & $24.6-74.7$ & $44.16 \pm 10.93$ & $4(3)$ & & & & \\
\hline Renal cell carcinoma & 47 & 30 & $29.7-192.0$ & $73.62 \pm 36.92$ & $15(50)$ & 17 & $18.0-61.0$ & $38.76 \pm 14.46$ & $3(18)$ \\
\hline Uroepithelial tumor ${ }^{c)}$ & 53 & 44 & $17.4-221.7$ & $49.66 \pm 41.43$ & $6(14)$ & 9 & $25.2-58.5$ & $38.44 \pm 10.15$ & $1(11)$ \\
\hline Prostate cancer & 33 & 33 & $26.2-191.9$ & $54.61 \pm 32.14$ & $6(18)$ & & & & \\
\hline Other urological tumor & 25 & 25 & $18.5-69.9$ & $38.67 \pm 13.78$ & $1(4)$ & & & & \\
\hline Benign renal disease $e^{e)}$ & 21 & 20 & $28.4-128.7$ & $48.74 \pm 21.11$ & $1(5)$ & 1 & 31.8 & 31.8 & 0 \\
\hline Chronic renal failure & 28 & 20 & $30.0-79.0$ & $40.40 \pm 12.06$ & $1(5)$ & 8 & $33.1-157.5$ & $64.21 \pm 42.61$ & $3(38)$ \\
\hline BPH & 25 & 25 & $24.6-60.7$ & $41.36 \pm 11.04$ & 0 & & & & \\
\hline Prostatitis/epididymitis & 9 & 9 & $23.8-70.2$ & $48.73 \pm 13.53$ & $1(11)$ & & & & \\
\hline Metastatic renal tumor") & 2 & 2 & $45.1-58.0$ & 51.55 & 0 & & & & \\
\hline
\end{tabular}

a) b) : 67 and 49 G-R unit were upper normal limits in normal males and females, respectively, determined by mean $+2 S . D$. of serum P-LAP values in normal controls.

c) consist of 15 of renal pelvic tumor $(M: F=11: 4), 8$ of ureteral tumor $(6: 2)$ and 30 of bladder tumor $(27: 3)$.

d) consist of 20 of testicular tumor, 4 of penile cancer and 1 of scrotal tumor.

e) consist of 7 of renal cyst $(M: F=7: 0), 8$ of renal stone $(8: 0)$ and 6 of hydronophrosis due to ureteral stone (5:1).

f) tumors came from bone and lung. 


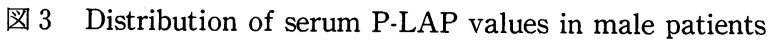

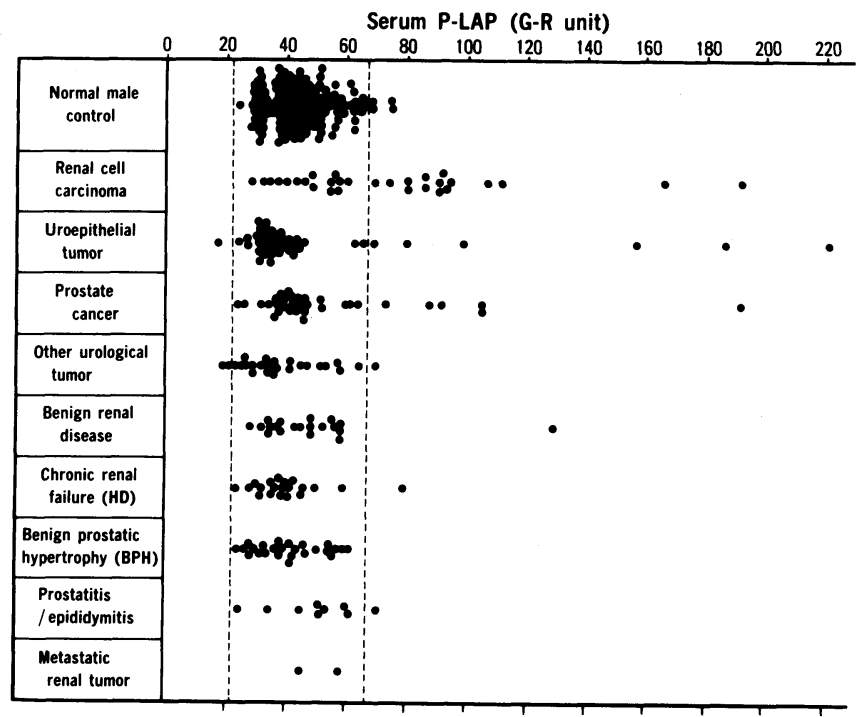

Two broken lines indicate normal range of serum P-LAP values in males (22-67 G-R unit).

図 4 Distribution of serum P-LAP values in female patients

Serum P-LAP (G-R unit)

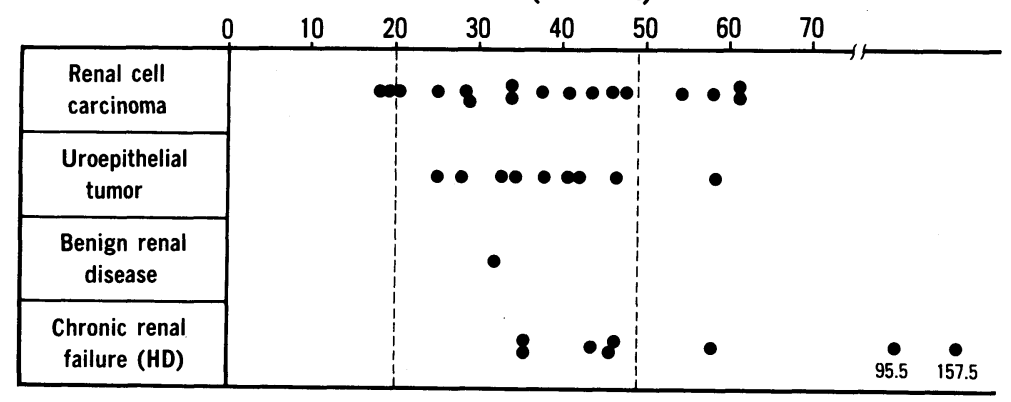

Two broken lines indicated normal range of serum P-LAP values in females (20-49 G-R unit).

図 5 Comparison between serum P-LAP and socalled LAP values

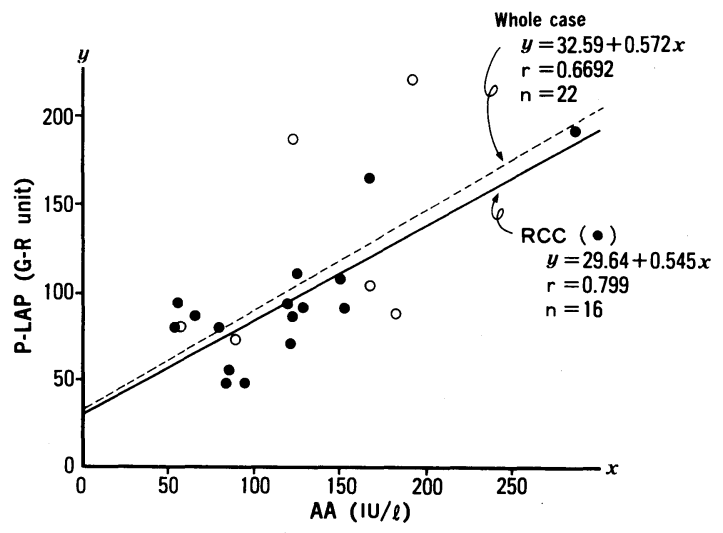

值内での変動か，正常値から高值への変動を示してい た（図 6 ).こうした傾向は，いわゆるLAP値での解 析では，明らかでなかった（図 7 ).

$$
\text { 考察 }
$$

腫瘍産生物質, または腫瘍存在時生体が反応性増加 を示す物質が，血液をはじめとする体液中に出現し， 生化学的に測定することができ，悪性腫崵の診断と経 過観察の目的で用いられている腫瘍マーカーは, 感度 と特異性が高ければ，単に「癌の存在」のみだけでな く，その癌の生物学的悪性度をあわせて評価しらる点 で，画像診断技術之同様に，悪性腫瘍患者の監理に欠 くことのできない手段の 1 つと言うことができよう. 事実, 泌尿器科領域に扮いても, 辠丸腫瘍に拈ける $\alpha$ 
図 6

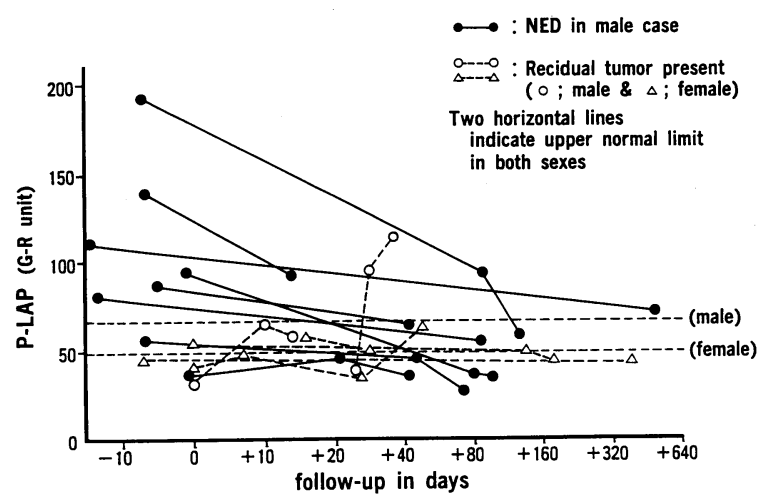

図 7

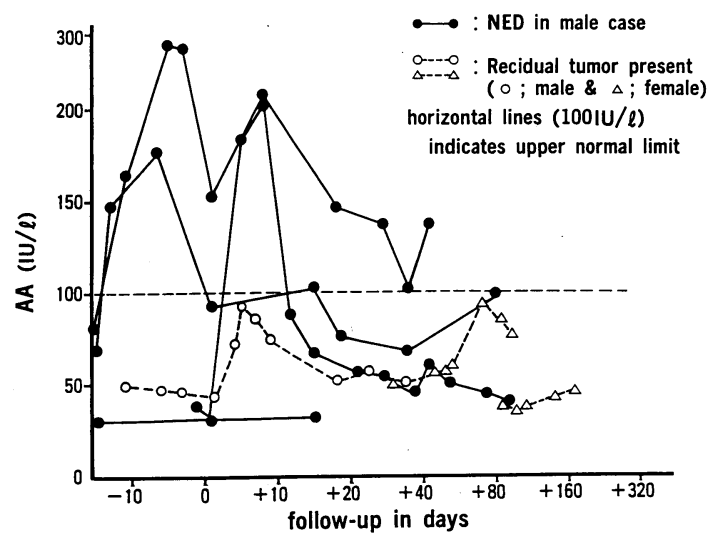

fetoprotein, HCG- $\beta$ subunit は, 癌細胞産生物質とし て, また, 前立腺癌の prostatic acid phosphatece (PAP) p prostate tissue-specific antigens (PA, $\gamma$-Sm など）は，組織特異抗原として，有用なマーカーとし
ての評価をらけている。

しかし，腎細胞癌に拈いては，いうした特異的マー

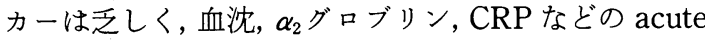
phase reactant が多用されている2)5) に過ぎず，いずれ の物質を用いても，かなり多くの鑑別診断を行なって のち本疾患に到達できるのにすぎず，また，retrospec tiveにはともかくも，早期診断の手技にはなりえな かった.さらに, basic fetoprotein (BFP), tissue peptide antigen (TPA), immunosuppressive acid protein (IAP) の評価を行なった神田らの報告6)でも， BFP の陽性率は $30 \%$ と低感度であり，TPA について も同様結果であった，IAP については, 高感度であっ

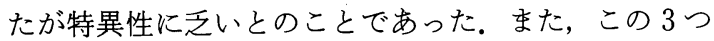
のマーカーのいずれかが高值であっても, 他臓器悪性 腫瘍との鑑別診断を要することは論を待たない.さら に，最近では，鈴木ら 腎細胞癌の病期, prostaglandin $\mathrm{F}$ 值と細胞分比度と の相関があること，おのおののマーカーで $40 \%$ 前後の 陽性率を示すとの報告もある。乙かし, 腎細胞癌の現 時点での唯一の根治手段は，早期発見・根治手術であ り,インターフェロンを初めとする化学療法, 放射線 療法も一定の確立された方法は, 未報告であり, この 意味に扣いても, specificなマーカーの確立が待たれ る点でもあった。

placental leucine aminopeptidase (P-LAP) は，妊 婦の胎盤機能の指標として広く用いられている ${ }^{8) 9)}$ が,

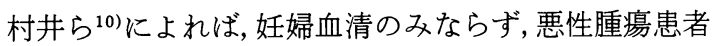
血清中にも高値例が散見されるようになり, 本酵素の 腫瘍マーカーとしての意義が注目されている. 本論文 は，この P-LAP の腎細胞癌における臨床的意義につ

表 3

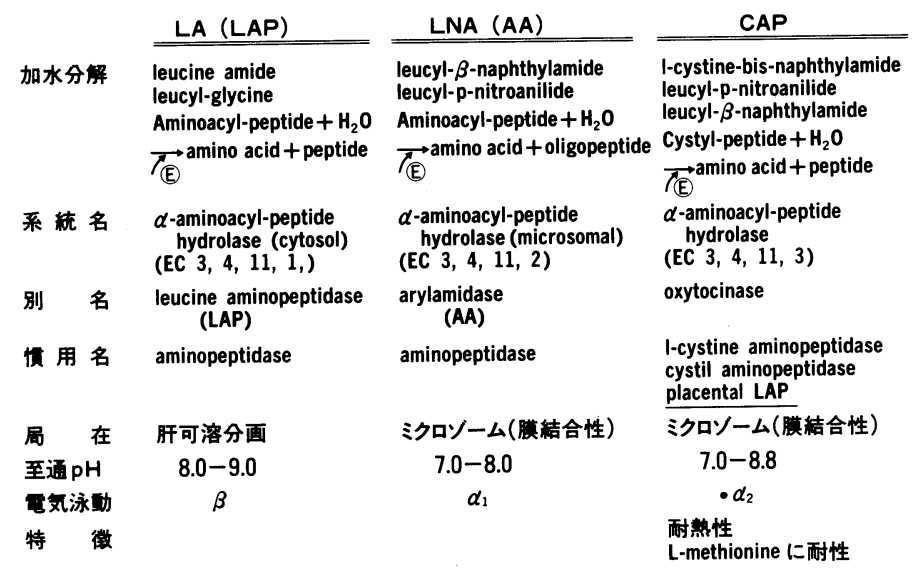


いて検討した preliminary な報告である。周知のよう に, aminopeptidase は, ペプタイドをアミノ基末端か ら加水分解する酵素の総称であり, 各酵素間の基質特 異性が乏しいのが特徴である。表 3 は, 各種文献311112) からまとめた aminopeptidase の特徵の一覧であり, P-LAPは, cystine aminopeptidase (CAP) (EC 3, $4 ， 11 ， 3 ）$ と同一の酵素々みなされている．今回の検 討で基質として用いた 1-leucyl-p-diethylaminoanilide も，P-LAP のみならず arylamidase (AA) に よって, よく加水分解されるため, $2 \mathrm{mM}$ の $\mathrm{L}$. methionine の共存によって, AA 活性を阻害させ, P-LAP 活性のみを測定したものである.

血清 P-LAP 值の正常值は, 今回の135例の健常男性 例の検討では, 24.6 74.7G-R unitに分布しており， 平均 +2S.D. 值より，67G-R unit 未満とした。村井ら の報告 ${ }^{10)}$ では, 514例の男女例での測定で3 $15 \mathrm{mU} / \mathrm{ml}$ （12.4〜61.9G-R unit）に分布しており，泳ぼ一致した 成績であった。男性例の陽性率は，腎癌50\%，前立腺 癌 $18 \%$, 尿路上皮腫瘍14\%が主であり，P-LAP の腎細 胞癌検出の感度 $50 \%$ は，さほどでもなかったが，特異 性（94\%，162/178）は優れた結果であった。また， Students' t test でも，少なくとも5\%の危険率で，腎 細胞癌群は, 血清 P-LAP 值が高值を示すことが証明

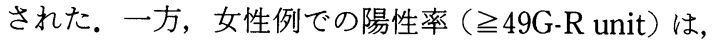
腎細胞癌 $18 \%$ ，尿路上皮腫瘍 $11 \%$ ，血液透析中の慢性 腎不全 $38 \%$ と, 腎不全患者の血清 P-LAP 值が, 有意に 高値であった，検討症例数が多くないため，この原因 は推測できないが, 後述するょうに, P-LAP 值と AA 值間の相関性が高く, 食餌療法・ヘパリン使用など, 腎不全患者においては，いずれか高值を示しているか 興味深い点であった。ささに，14例と多くない症例で， 測定ポイントも 2,3 カ所にすぎないが, 経時的測定の 結果, 臨床経過とよく一致した成績が得られた。これ は, いわゆるLAP 值での解析では得られない現象で あった。いずれにしても, この結果から, 本酵素は, 男性例では，少なくとも尿路疾患に拈いて高い特異性 と, 中等度の感度を示す腫瘍マーカーとなりらる可能 性を示唆していた。

日常, 臨床検査で測定されている“LAP”活性は, 大 部分 AA 活性であり ${ }^{11)}$, 今回測定された P-LAP 值と の相関をみると， $\gamma=0.669$ と高度であった。これは, 日和田ら ${ }^{13)}$ が述べているように, 20mM L-methionine 添加でも，AA 活性は完全に失活せず，一方で P-LAP 活性もある程度阻害されるためと考兄られた。このた
め, 本測定系では, P.LAP の大部分 $+\mathrm{AA}$ の一部を合 わせ断定していることになり，非妊婦の担癌状態の患 者では, P-LAP の体液内放出が大量でないため, 問題 となりらるものと考えられた。この観点から，P-LAP に特異的な合成基質が望みにくい現状では，免疫学的 測定法の開発が焦眉であり，開発された方法を用いる ことによって, P-LAP の腎細胞癌における腫瘍マー カーとしての意義がより明確になるものと思われた。

\section{結 語}

腎細胞癌における腫瘍マーカーとしての胎盤性ロイ シンアミノペプチダーゼ (P-LAP) の意義を臨床的に 検討した。測定は, 酵素法で行ない, 合計243例の尿路 疾患で解析した。男性67, 女性49G-R unit の正常上限 值を越寸陽性率は, 腎細胞癌(男 $50 \%$, 女 $18 \%$ )，尿路 上皮腫瘍 (男 $14 \%$, 女 $11 \%$ ), 前立腺癌 $18 \%$, 良性腎疾 患（男 $5 \%$ ，女 $0 \%$ ), 慢性腎不全（男 $5 \%$ ，女 女8\%） であった，男性例では，本酵素を用いた腎細胞癌の生 化学的診断上の感度は $50 \%$, 特異性 $94 \%$ であった。 た，14例の腎細胞癌患者の臨床経過を血清 P-LAP 值 の変動もよく一致していた. しかし，他の aminopeptidase との交叉反応はさけられず, 免疫学的測定法 の開発が必須であろらと思われた。

稿を終わるにあたり，血清の採取など御協力いただきま した関連病院の諸先生に深謝いたします。な拉, 本研究の一 部は, 文部省科研費（No. 60480355）によって行なわれた ことを付記します。

本論文の要旨は, 第24回日本癌治療学会総会(1986年, 松 汇）に打いて発表した。

文献

1) Warren, B. and Perlmann, P.: Bladder and renal tumor markers. Human Cancer Markers, p. 303, Human Press, Clifton, 1982.

2）上田豊史：腫敫マーカーに関する研究の現況と展 望一腎細胞癌一. 西日泌尿, 45, 235-240，1983.

3）尾形 稔, 杉田 収：ロイシンアミノペプチダー ゼ(LAP). 酵素の検査診断学, p. 115, 宇宙堂八 木書店, 東京, 1984 .

4）日本ヶミファ（株）：P-LAPテスト添付文書.

5）里見佳昭：腎癌の予後に関する臨床的研究一々く に生体側の因子を中心に一。日泌尿会誌，64， 195-216, 1973.

6）神田裕三, 石井 勝, 田利清信, 佐竹一郎：腎癌に 㧊ける腫煌マーカーの有用性について。臨泌，39, 579-583, 1985.

7）鈴木明彦, 増田宏明, 大田原佳久, 鈴木和雄, 田島 淳, 阿曾佳郎：腎癌と血中腫瘍マーカー. 日泌尿会 誌, 77, 87-91，1986. 
8）水谷栄彦：母体情報としての血清酵素 -Placental leucine aminopeptidese (P-LAP) を 中心に一. 臨婦産, 35, 661-666, 1981.

9）秋山治幸, 水谷栄彦, 成田 収, 友田 豊, 佐伯明 彦: 妊娠時に打ける血中 placental leucine aninopeptidase (P-LAP) の動態. 日産婦会誌, 36, 2605-2612, 1984.

10) 村井哲夫, 及川 淳：シスチンアミノペプチダー ゼ(CAP)の臨床的意義. 臨床病理, 28, 1020-1024,
1980.

11）菅野剛史：ロイシンアミノペプチダーゼ。臨床病 理, 特43, 102-111, 1981 .

12）熊坂一成, 関口光夫：シスチンアミノペプチダー ゼ. 臨床病理, 特55, 156-166, 1983.

13）日和田邦男, 国府達郎：Cystine aminopeptidase (CAP) の生化学. 産科と婦人科, 48, 971-976, 1981.

（1986年12月25日受理） 